\title{
Pricing Agreement and its Importance for the Tax Control of Transactions between Related Parties
}

\author{
Ajdar M. Tufetulov ${ }^{1}$, Fatih Sh. Nugaye ${ }^{2}$, Andrey S. Zayats ${ }^{3}$ \\ 1, 2, 3 Kazan Federal University, Institute of Economics and Finance \\ Email: zayatsas@yandex.ru , Contact: +79297226790
}

Received: 21st October 2017 Accepted: 16th November 2017, Published: 31st December 2017

\begin{abstract}
Due to the variety of approaches to determining correspondence of book prices to market prices, the system of tax control of transactions between interdependent persons creates inconvenience for both organizations and tax authorities: it is necessary to look for comparable prices, and to prove the possibility of using a particular method of pricing. For the harmonization and simplification of relations between taxpayers and tax authorities, the Tax Code of the Russian Federation provides for the possibility of concluding a pricing agreement [1].

The pricing agreement for tax purposes is an agreement between a largest taxpayer and the Federal Tax Service of the Russian Federation on the procedure for determining prices and applying pricing methods in transactions between interdependent persons.

The main purpose of the pricing agreement is achievement of certainty in the methods and process of determining by the taxpayer the prices used in transactions between interdependent persons for both taxpayers and tax authorities, and achievement on this basis of the contractual consolidation for all the terms of the transaction process of interdependent persons between a taxpayer and the tax authorities [2].

In connection with the foregoing, the relevance of the topic of the paper is in the consideration of the mechanism of the pricing agreements that allow defining clear "rules of the game" for both taxpayers and tax authorities in the process of tax control of transactions between interdependent persons.
\end{abstract}

Keywords: Interdependent Persons, Pricing Agreement, Transfer Pricing, Tax Code of the Russian Federation, Organization for Economic Cooperation and Development.

\section{Introduction}

Currently, the procedure for concluding a pricing agreement is provided for in Ch. 14.6 of the Tax Code of the Russian Federation, which regulates the procedure for the conclusion, duration and procedure for termination of a pricing agreement for tax purposes [2].

At the conclusion of the agreement, the tax authorities are guided, in addition to the Tax Code of the Russian Federation, by the Russian Federation's agreements on avoidance of double taxation, and by the Guidelines of the Organization for Economic Cooperation and Development on Transfer Pricing for Transnational Companies and Tax Administrations [3].

The authors of the paper have proposed the stages of the process on concluding a pricing agreement. The stages of concluding a pricing agreement are the following:

- Preliminary stage (submission by the taxpayer of the application and documents necessary for the conclusion of the pricing agreement);

- A stage of consideration of documents of the tax bearer (decision-making on carrying out of the pricing agreement);

- A stage when the pricing agreement is in effect.

\section{Materials and Methods}

At the preliminary stage of concluding a pricing agreement, a largest Russian taxpayer making controlled transactions must submit an application to the Federal Tax Service of the Russian Federation, as well as a list of mandatory and additional documents [4]:

- Accompanying documents to the application;

- Documents that justify the methodology for determining prices for tax purposes;

- Primary documents confirming the facts stated in the draft pricing agreement and justifying its documentation.

At the stage of consideration of documents submitted by the taxpayer, the Federal Tax Service of the Russian Federation considers them within six months from the date of receipt (the term may be extended up to nine months).

The following issues may be included in the pricing agreement, according to which an agreement is reached between the taxpayer and the Federal Tax Service of the Russian Federation [4]: 
- Types, lists of controlled transactions and goods (works, services) in respect of which the pricing agreement is concluded (for deals in the agreement, their prices will be recognized as corresponding to market prices);

- The procedure for determining prices, description and procedure for applying pricing methods for tax purposes;

- A list of sources of information used in determining the compliance of prices used in transactions to the terms of the agreement;

- A list, procedure and terms of submission of documents confirming the fulfillment of the terms of the pricing agreement.

The list of issues included in the pricing agreement is not closed. By agreement of the parties, other conditions for transactions between interdependent persons may be established therein.

At the stage of making a decision on concluding a pricing agreement, the Federal Tax Service of the Russian Federation decides [2]:

a) On the conclusion of a pricing agreement specifying the place, date and time of signing the agreement;

b) On the need to finalize the draft pricing agreement;

c) On the refusal to conclude a pricing agreement.

In case of a positive decision, the statement on possibility to conclude the pricing agreement shall be forwarded to the taxpayer within five days from the date of making such a decision. A copy of the pricing agreement concluded with the taxpayer is sent by the Federal Tax Service of the Russian Federation to the tax authority at the taxpayer's place of registration in the capacity of a largest taxpayer within three days from the date of signing the pricing agreement [5].

If it is necessary to finalize the draft agreement, the decision should contain references to the submitted documents, revision of which by the taxpayer is required. After finalizing the documents, the taxpayer has the right to re-submit the draft pricing agreement, which is considered by the Federal Tax Service of the Russian Federation within three months from the date of the repeated filing of the documents. [5]

In the event of a refusal to conclude a pricing agreement, the Federal Tax Service of the Russian Federation makes a reasoned conclusion that as a result of the application of the price-setting procedure proposed by the taxpayer in the draft pricing agreement, pricing methods will not ensure price compliance [6].

The decision to refuse to conclude a pricing agreement may be appealed in court in accordance with the law. After reviewing the application, the arbitral tribunal may recognize the decision of the Federal Tax Service of the Russian Federation as appropriate or invalid. If the decision of the Federal Tax Service of the Russian Federation to refuse to conclude a pricing agreement is declared invalid, the tax authority will subsequently have a duty to decide on concluding a pricing agreement. If the arbitration court recognizes the decision of the Federal Tax Service of the Russian Federation as relevant to the legislation, the taxpayer must make changes to the draft pricing agreement [2].

After eliminating the reasons reflected in the relevant decision for the refusal of the tax authority to enter into a pricing agreement, the taxpayer will have the right to apply again to the Federal Tax Service of the Russian Federation for conclusion of a price agreement [6].

After signing the pricing agreement on time and at the location specified in the decision to conclude a pricing agreement, the Federal Tax Service of the Russian Federation sends its copy to the tax authority at the place of registration of the largest taxpayer within three working days from the date of its signing.

At the stage when the pricing agreement is in effect, it begins to be effective from January 1 of the next calendar year following the year of its signing [7]. The pricing agreement ceases to be valid at the end of the term for which it was concluded. In exceptional cases, the pricing agreement may be terminated before the expiration of the period for which it was concluded by agreement of the parties or by a court decision. Also, the Federal Tax Service of the Russian Federation may decide to early termination of the agreement if the taxpayer violates its terms during the term of its operation, which entailed incomplete payment of taxes [4].

When changing the legislation on taxes and fees concerning to the relations regulated by the pricing agreement, the terms of the concluded agreement remain unchanged until the expiration of its validity.

\section{Results and Discussion}

The authors of the paper propose an algorithm for concluding, effect and termination of a pricing agreement as a result of their analysis of the tax control stages for transactions between interdependent persons. As already mentioned above, the algorithm of pricing agreement effect includes the following stages:

- Preliminary stage;

- A stage of consideration of the tax bearer's documents;

- A stage of the making decision to review the pricing agreement;

- A stage when the pricing agreement is effective

A process of concluding a pricing agreement is shown in Figure 1 in the form of an algorithm. 


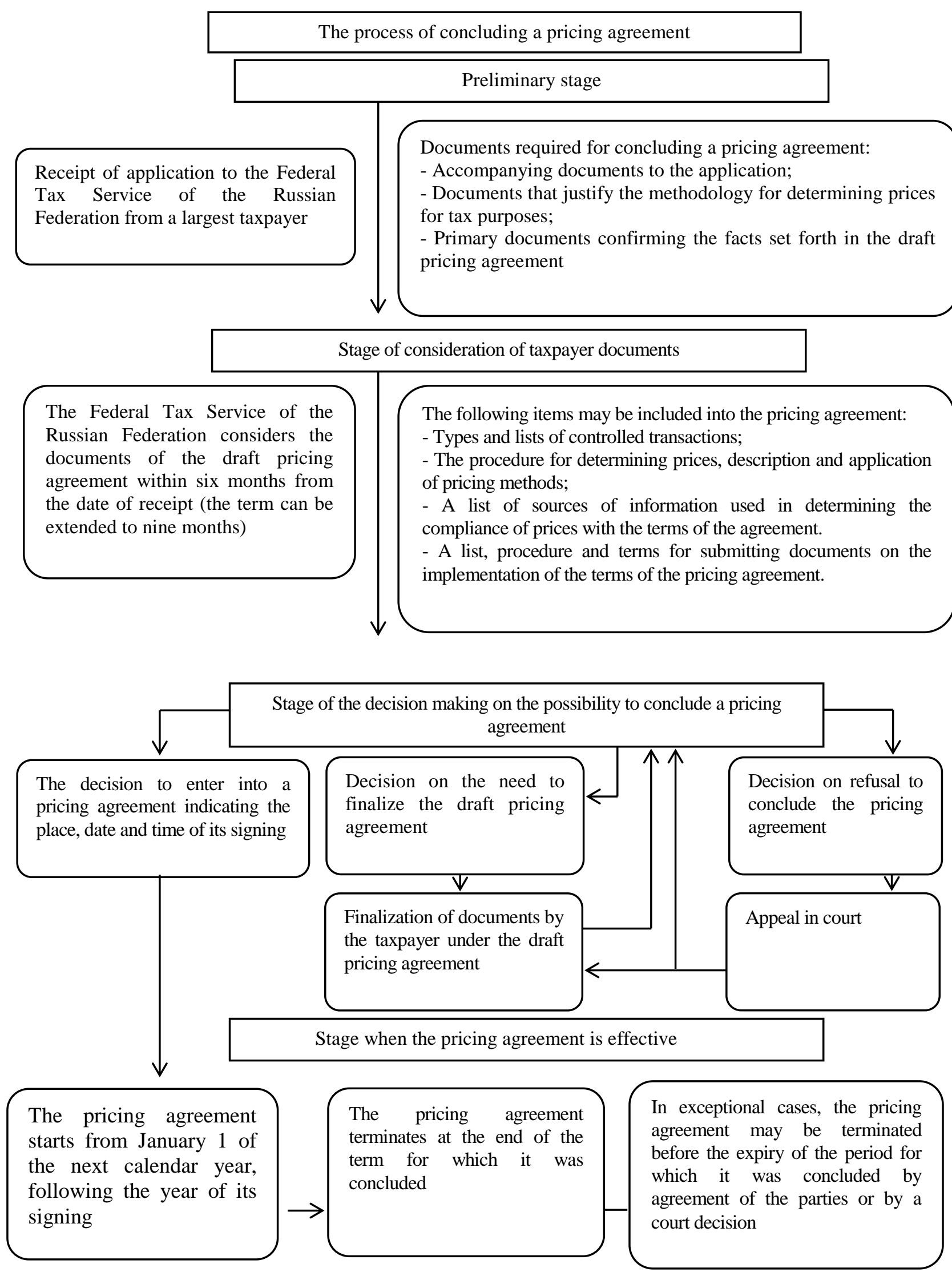


In the Russian Federation to date, pricing agreements with the tax authority has been concluded by the three largest taxpayers: Rosneft, Gazpromneft and Aeroflot. On the whole, eight pricing agreements have been concluded, under which the tax authorities will only verify the compliance of companies with the terms of the pricing agreement, and not the approaches to determining the validity of the applied prices in transactions between interdependent persons. The prerequisite for pricing agreements is the transparency of price setting by taxpayers [8].

\section{Summary}

In the opinion of the authors of the paper, on the one hand, the conclusion of a pricing agreement has problematic moments for some taxpayers, since it is possible the following [9]:

- Inexpediency of concluding a pricing agreement (in a situation where the costs of concluding an pricing agreement and compliance with its conditions exceed requirements arising from the conditions for the implementation of Section V.1 of the Tax Code of the Russian Federation);

- Non-compliance with the criteria for the possibility of concluding a pricing agreement (for example, if the taxpayer is not the largest);

- Additional charging of taxes, penalties and fines with respect to transactions between related parties which prices have been agreed in the pricing agreement.

On the other hand, there are advantages of concluding a pricing agreement, which have been pointed out by

L. P. Grundel for both tax authorities and taxpayers [2]:

- Effective interaction between a taxpayer and the tax authorities;

- Saving resources for conducting protracted and laborintensive tax audits and litigation;

- Higher level of transparency of taxpayer information when tax authorities conduct tax control procedures;

- Effective interaction between Russian tax authorities and tax authorities of foreign countries;

- Elimination of the double taxation problem (under bilateral pricing agreements).

\section{Conclusions}

Thus, pricing agreements being an instrument in domestic tax practice introduced by Law No. 227-FZ dated July 18, 2011 is another step in harmonizing the Russian tax system with international rules for controlling transactions between interdependent persons. According to O. V. Chaadaeva, conclusion of a pricing agreement allows considerably to simplify the procedure of tax administration of the largest taxpayers and to reduce the costs of taxpayers in connection with the conduct of tax controls. A pricing agreement for tax purposes allows the taxpayer and the tax authority to determine the market price of transactions on the basis of which tax liabilities are calculated before the actual execution of transactions [10].

Ultimately, according to the authors of the paper, conclusion of a pricing agreement can allow taxpayers to reduce the level of costs associated with implementing measures to meet the requirements of the law on setting prices in transactions for tax purposes, and to reduce the administrative burden of tax authorities associated with the implementation procedures for controlling transactions between interdependent persons.

\section{Acknowledgements}

The work is carried out according to the Russian Government Program of Competitive Growth of Kazan Federal University.

\section{References}

[1] The Tax Code of the Russian Federation (Part One). Approved by the Order of the Ministry of Finance of the Russian Federation dated 13.07.1998. No. 146-FZ (as amended on 08/06/2015) // SPS "Consultant Plus". - Legislation: Prof. Version - Access mode: http://base.consultant.ru (accessed date: 01/05/2017).

[2] Grundel L. P. Pricing agreements as a new form of tax control over transfer pricing in the Russian Federation / L. P. Grundel // Finance and credit. - 2014. - No. 10.

[3] Zadorozhnaya A. I. Pricing agreement for tax purposes in the Russian Federation in the light of international tax planning // Judicial practice in Western Siberia. - 2015. - No. 1. - P. 19-37.

[4] Chaadaeva O. V. Tax control over pricing for office and field tax audits / O. V. Chaadaeva // Finances and Tax Policy. - 2012. - No. 3. - P. 189-194.

[5] On Amending Certain Legislative Acts of the Russian Federation in Connection with the Improvement of the Principles for Determining Prices for Tax Purposes: Federal Law No. 227-FZ dated July 18, 2011 // RossiyskayaGazeta. -2011. №5535.

[6] Shestakova E.V. Conclusion of tax agreements // Russian legal journal. - 2016. - No. 3. - P. 195-201.

[7] Petukhova R.A. World practice of tax regulation of transfer pricing and the direction of its development // Innovative development of the economy. - 2016. - No. 3-1 (33). - P. 105-110.

[8] Artzhanova M. M. Tax risks of the largest taxpayers and the state // Information as the engine of scientific progress: a collection of papers of the 
international scientific and practical conference: in 3 parts. - 2017. - P. 12-17.

[9] Kirpikov A.N. Relevant approaches to performing analysis of financial results of organization's activity with application of factor models / A.N. Kirpikov, F.S. Nugaev // International Business Management. Volume 10. - Issue 15. - 2016. - Pages 2987-2991.

[10] Tufetulov A.M. Transaction tax control algorithm between related persons A.M. Tufetulov, F.S. Nugaev, A.S. Zayats // International Business Management. Volume 9. - Issue 7. -2015. - Pages 1785-1791 